\title{
Analisis User Interface Meningkatkan Pengalaman Pengguna Menggunakan Usability Testing pada Aplikasi Android Course
}

\author{
Wira Buana ${ }^{1}$, Betha Nurina Sari ${ }^{2}$ \\ ${ }^{1,2}$ Universitas Singaperbangsa Karawang \\ email: wira.buana18024@student.unsika.ac.id'1 , betha.nurina@staff.unsika.ac.id ${ }^{2}$
}

\begin{abstract}
User Interface is a visible show of a product that serves to bridge the gadget with the person or user, wherein the UI show may be inside the form of colours, shapes and interesting writing on mobile applications. With a lack of preparation and immature design, the mobile application is less running optimally and causes users to want to move to another application. The purpose of this study is the analysis of user interface levels in online android course applications using usability testing. The study was conducted using usability testing using the SUS method by measuring user satisfaction with 10 questions online. This research information data obtained online is a user of this internet-based android online course application will give direct effect to users to the online course android application that is held. The data sample taken in the study was 30 students who tried this application. In this technique, the analysis of information research data used is a descriptive analysis with a percentage of data, then described to measure the level of ease of use in the online android course application. The results of this study the score obtained through questionnaires distributed online got a score of SUS 78.3. on the acceptability stages aspect occupies the marginal excessive stage, at the adjective aspect the score is inside the OK position, and lastly on the grade scale aspect occupies grade $B$.
\end{abstract}

Keywords: Analysis, Usability Testing, User Iterface

\begin{abstract}
Abstrak: User Interface adalah tampilan dari sebuah produk yang berfungsi menjembatani sistem dengan pengguna atau user, dimana tampilan UI bisa berupa warna, bentuk serta tulisan yang menarik pada aplikasi mobile. Dengan kurangnya persiapan dan rancangan yang belum matang, maka pada aplikasi mobile tersebut kurang berjalan maksimal dan mengakibatkan pengguna ingin berpindah ke aplikasi yang lain. Tujuan penelitian ini yaitu analisis tingkat user interface pada aplikasi android Course Online menggunakan usability testing. Pada penelitian ini dilakukan dengan menggunakan usability testing yaitu pengujian usability menggunakan metode SUS dengan mengukur kepuasan pengguna dengan 10 pertanyaan secara online. Penelitian ini data informasi yang didapat secara online ini adalah pengguna aplikasi Course Online android berbasis internet ini akan memberikan langsung efek kepada pengguna terhadap aplikasi android Course Online yang dilangsungkan. Sampel data yang diambil dalam penelitian ini adalah 30 orang mahasiswa yang mencoba aplikasi ini. Dalam teknik ini analisis data penelitian informasi yang digunakan merupakan analisis deskriptif dengan persentase data, kemudian dideskripsikan untuk mengukur tingkat kemudahan penggunaan dalam aplikasi android Course Online. Hasil dari penelitian ini skor yang di dapat melalui kuesioner yang disebarkan secara online ini mendapatkan skor SUS 78,3. Pada sisi acceptability ranges menempati level marginal high, pada sisi adjektif rating berada pada posisi OK, dan terakhir pada sisi grade scale menempati grade B.
\end{abstract}

Kata kunci: Analisis, Usability Testing, User Interface

\section{Pendahuluan}

Teknologi pada zaman sekarang cukup membantu masyarakat untuk mendukung aktivitasnya. Teknologi pada dunia pendidikan memudahkan dalam proses pembelajaran (Geasela et al., 2018).
Teknologi sebagai alat untuk membantu urusan manusia. Dalam dunia pendidikan teknologi mampu mentransformasikan

model pembelajaran yang dulu dilakukan secara langsung melalui tatap muka, kini bisa dilakukan secara online di 
manapun, setiap saat dan oleh sejumlah orang.

Pada zaman sekarang aplikasi Android mulai digunakan sebagai pembelajaran e-learning, sehingga aplikasi android dianggap penting juga aplikatif untuk menjadi solusi dalam tantangan yang ada pada zaman sekarang. Salah satunya adalah dengan cara menciptakan operasi mobile yang bisa mendapatkan informasi instruksional yang presto, akurat dan benar-benar.

Sebuah perangkat lunak dengan perangkat lunak lain mempunyai desain antarmuka yang tidak selaras, sebagai akibatnya wajib di sesuaikan menggunakan fungsi dan kebutuhan aplikasi yang user butuhkan.

Salah satu media pembelajaran secara e-learning ini mengintegrasikan berbagai kegiatan dan layanan masyarakat yang mencakup kurikulum berdasarkan kebutuhan industri, penilaian "Auto Grading", personalisasi proses pembelajaran dan sertifikasi. Aplikasi berbasis android ini bernama Course Online. Aplikasi Course Online ini dibuat untuk memudahkan masyarakat dalam menjalani aktivitas pembelajaran secara e-learning oleh sebab itu, aplikasi Course Online diharapkan sebagai aplikasi yang mudah digunakan oleh siapapun.

Aplikasi Course Online pada gambar 1 menyediakan pembelajaran di bidang teknologi, seperti Pemrograman Web, UI/UX Design, Data Mining, dan lain-lain. Aplikasi ini bisa digunakan oleh pengguna dengan gratis dan berbayar berdasarkan fitur dibutuhkan. Bagi pengguna yang sudah menyelesaikan pembelajaran akan mendapatkan sertifikat kompetensi.

Untuk membuat sistem operasi Android yang benar dan baik, maka salah satu bagian yang penting untuk diperhatikan adalah usability. Elemen kegunaan merupakan prinsip penting dalam menentukan keberhasilan suatu produk atau operasi dengan menilai antarmuka stoner yang digunakan (Hartawan, 2019). Walaupun sistem pembelajaran secara e-learning sudah banyak digunakan, tidak semua sistem aplikasi pembelajaran secara $e$ learning telah melalui tahap pengujian dan pengukuran usability. Maka dari itu Course Online ini akan dievaluasi dengan wawancara dan membagikan kuesioner kepada responden yang sudah ditetapkan kriterianya.

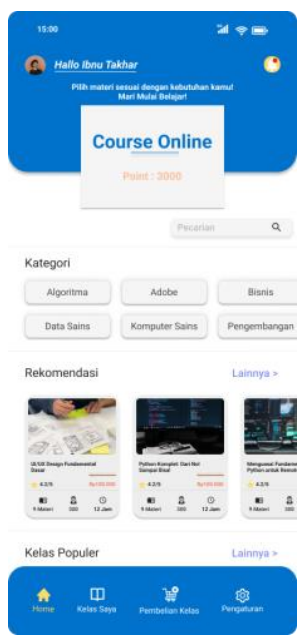

Gambar 1. Tampilan laman aplikasi Course Online

Tanggapan dari user terhadap aplikasi Course Online ini sebelum dievaluasi interfacenya yaitu menunjukan $16,10 \%$ penilaian yang diberikan responden terhadap tampilan aplikasi Course Online. Penting untuk dipahami bahwa peran daripada pengguna sangat dibutuhkan dan adalah sebuah bagian utama dalam mengembangkan aplikasi ini dan juga kemajuan suatu pembelajaran yang mudah termotivasi. Berdasarkan realita ini, maka penting untuk melakukan sebuah evaluasi yang bertujuan untuk menemukan dan mengamati sejauh mana prinsip daripada usability dalam penerapannya pada aplikasi Course Online. ISO 9241:11 mengemukakan bahwa proses pengukuran dari pada usability ini terdiri dari 3 bagian (Veitch et al., 2021), yaitu: 
1. Efektif (Effectiveness), merupakan ketetapan daripada pengguna dalam lingkungannya untuk memperoleh tujuan tertentu.

2. Efisien (Effisciency), kemampuan daripada pengguna untuk memahami produk atau aplikasi untuk mencapai tujuan.

3. Kepuasan (Satisfaction), kebebasan dari ketidaknyamanan dan perilaku yang bersifat positif dari sebuah produk.

Adapun tujuan dilakukannya penelitian ini adalah untuk mengukur bagaimana tingkat usability pada aplikasi Course Online yang diukur dengan menggunakan ketiga aspek dalam usability. Oleh karena itu, dibutuhkan sebuah perancangan user interface aplikasi Course Online dengan memperhatikan akan prinsip daripada usability pada aplikasi tersebut.

Ada beberapa penelitian sebelumnya yang menerapkan metode System Usablity Scale (SUS) untuk mengukur tingkat usability pada rancangan user Interface. Pada penelitian ini (Damayanti et al., 2022) mengukur SUS pada perancangan website apotek. Pada penelitian ini (Maryati et al., 2022) menerapkan metode SUS untuk analisis usability situs perpustakaan UC. Metode SUS juga digunakan untuk analisis usability pada aplikasi Frostid, aplikasi laporan banjir secara online (Pratama et al., 2021). Hasil penelitian (Aji \& DPA, 2020) menunjukkan bahwa penerapan metode SUS untuk analisis pada aplikasi Digilib dapat menjadi acuan pengembangan selanjutnya.

\section{Metode}

Dalam penelitian ini akan menggunakan metode penelitian deskriptif yaitu, sebuah metode yang berguna untuk menemukan serta memahami dan menarik kesimpulan tentang pengetahuan yang seluasluasnya dari subjek kajian pada suatu masalah tertentu (Ependi et al., 2017).
Alur penelitian bisa dilihat pada Gambar 2. Alur pertama yaitu mengindentifikasi masalah, yang merupakan bagian asal proses penelitian, yang bisa dipahami menjadi upaya buat mengidentifikasi persoalan yg terdapat serta membuat problem tersebut menjadi kenyataan, diukur serta diuji dengan metode yang akan digunakan. Langkah kedua yaitu menyebarkan kuesioner kepada responden, pada langkah ini kriteria untuk menyebarkannya ini yaitu mahasiswa dan pekerja yang akan menilai aplikasi Course Online dan meminta kepada para responden agar menjawab 10 pernyataan dari SUS. Pada tahap terakhir yaitu kesimpulan yang dimana berisi tentang hasil keseluruhan analisis data yang didapat.

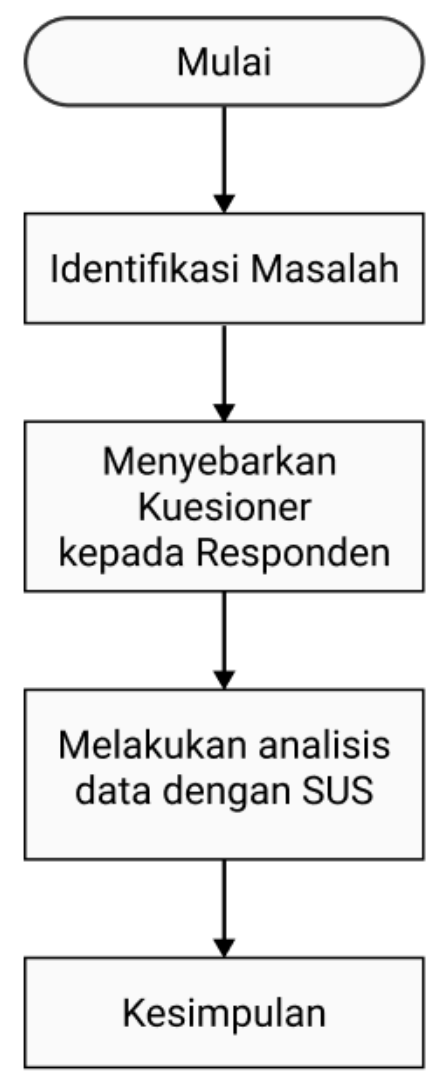

Gambar 2. Alur Penelitian

\section{User Interface (UI)}

Sebuah sistem atau aplikasi yang dapat dikatakan mudah dalam penggunaannya, ketika menggunakan 
tampilan yang baik juga mudah dimengerti oleh pengguna dari segi fitur tampilan lainnya pada aplikasi itu. Para penggunanya akan memberikan pendapat yang bersifat membangun dan juga memberikan feedback akan aplikasu yang digunakan dan hal ini akan mempermudah penggunanya dalam proses yang dilakukan (Nugraheny, 2016).

\section{Pengujian Usability}

Pengujian usability (Utami et al., 2020) adalah cara untuk mengevaluasi dan menguji pengalaman pengguna (UX) dari aplikasi atau sistem yang dibuat untuk pengguna. Pendekatan ini biasanya diambil oleh pengembang UX yang melibatkan pengguna tertentu untuk menguji bagaimana suatu proses berinteraksi dengan aplikasi atau sistem untuk mengukur kegunaan atau kemudahan(Fitriansyah \& Harris, 2018).

\section{System Usability Scale (SUS)}

Skala kegunaan sistem (SUS) adalah kuesioner untuk mengukur kegunaan yang dirasakan dan memiliki sepuluh pernyataan dengan 5 opsi respon buat responden, yang terdiri dari sangat setuju dan sampai kepada sangat tidak setuju untuk mengukur kegunaan sistem menurut sudut pandangan penilaian subjektif user (Sidik, 2018). Metode System Usability Scale (SUS) yang dipopulerkan pada tahun 1986 oleh John Brooke. Dalam mengevaluasi berbagai jenis produk dan layanan, yang didalamnya juga termasuk perangkat keras, lunak, seluler, situs web dari aplikasi, juga dapat menggunakan metode ini (Rasmila, 2018).

\section{Metode Analisis Data}

Analisis data yang diguanak di dalam penelitian yang dilakukan ini ialah metode system usability scale (SUS). Pada metode SUS ini memiliki sepuluh pernyataan dalam pengujian aplikasi atau sistem. Pada tahap ini user yang digunakan berjumlah 30 orang mahasiswa dan pekerja dengan membagikan kuesioner online. Jumlah ini dapat menentukan permasalahan usability pada aplikasi tersebut (Yonata et al., 2020). Skala tes dimulai dari 1 sampai 5, dimana 1 adalah STS (sangat tidak setuju) dan 5 adalah ST (sangat setuju) untuk setiap pernyataan SUS.

\section{Metode Perhitungan SUS}

Jumlah daripada perhitungan dalam proses uji operasi Course Online menggunakan SUS akan dilakukan menggunakan aturan dalam proses penghitungan skor SUS sebagai berikut, menjumlahkan skor dari setiap replier mulai dari pernyataan Q1 sampai dengan Q10. Jika Anda sudah mendapatkan kuantum, jumlahnya dikalikan 2,5 untuk memperoleh nilai akhir sesuai dengan rumus Brooke (Muqoddas et al., 2020). Setelah mendapatkan hasil, terapkan juga rumus untuk mencari nilai ratarata, yaitu menjumlahkan nilai semua responden juga dibagi dengan jumlah responden.

Aturan penilaian menggunakan System Usability Scale (SUS). Terdapat beberapa peraturan untuk menjumlahkan skor SUS. Berikut merupakan peraturan-peraturan pada saat dilakukan perhitungan jumlah pada kuesionernya:

1. Setiap pertanyaan bernomor ganjil, jumlah dari setiap pertanyaan yang diperoleh dari skor pengguna akan dikurang dengan 1.

2. Setiap pertanyaan yang bernomor genap, jumlah akhir yang diperoleh dari nilai 5 dikurangi dengan skor pertanyaan yang diperoleh dari pengguna.

3. Skor SUS diperoleh melalui hasil penjumlahan skor untuk setiap pertanyaan dan kemudian akan dikalikan dengan 2,5.

4. Aturan penilaian digunakan untuk 1 responden. Untuk perhitungan lebih 
lanjut, skor SUS daripada masingmasing responden akan dicari skor rata-ratanya dengan cara melakukan penjumlahan terhadap seluruh skor dan kemudian dibagi dengan jumlah daripada responden. Berikut rumus menghitung skor SUS:

$$
\underline{x}=\frac{\sum x}{n}
$$

$$
\begin{aligned}
& \frac{x}{\sum}=\text { Skor rata-rata } \\
& \begin{array}{l}
\sum x=\text { Jumlah skor SUS } \\
n \quad=\text { Jumlah responden }
\end{array}
\end{aligned}
$$

\section{Hasil}

tahap Penentuan Responden Pada menggunakan SUS terdiri 30 responden. Karakteristik daripada responden yang terdiri dari nama, jenis kelaminnya, umur juga pekerjaan.

Penilaian Responden Tabel di bawah merupakan hasil dari sebagian data yang diperoleh 1 responden yang telah menilai, sebelum melakukan perhitungan dengan metode SUS. Ditentukan pada tabel 1 responden dengan kriteria usia 21 tahun dan jenis kelamin laki-laki.

Pada pengukuran SUS ini menggunakan 10 pertanyaan yang sama seperti yang dilakukan pada penelitian sebelumnya (Santoso, 2018).

Tabel 1 data yang diperoleh 1 responden

\begin{tabular}{cc}
\hline Pertanyaan & Skor \\
\hline Q1 & 5 \\
Q2 & 4 \\
Q3 & 4 \\
Q4 & 3 \\
Q5 & 4 \\
Q6 & 1 \\
Q7 & 4 \\
Q8 & 1 \\
Q9 & 5 \\
Q10 & 4 \\
\hline
\end{tabular}

Pada tahap selanjutnya data pada Tabel 1 kemudian dihitung dengan aturan sesuai dengan metode SUS masing-masing pertanyaan yang memiliki nomor yang ganjil skor pengguna akan dikurangi 1 dan masing-masing pertanyaan yang memiliki nomor yang genap, maka skor pengguna akan dikurangi 5 . Kemudian lakukan proses perhitungan skor SUS menjumlahkan skor pada penilaian responden yang dimulai dari Q1 sampai dengan Q10. Setelah dijumlahkan lalu dikali 2,5 untuk mendapatkan nilai akhir. Di bawah ini adalah hasil dari perhitungan 1 responden pada tabel 2 .

Setelah menyelesaikan tahap pada tabel 2 maka tahap selanjutnya yaitu mencari nilai rata-ratanya. Caranya dengan jumlahkan nilai dari semua responden lalu dibagi jumlah keseluruhan responden.

Tabel 2 data hasil hitung SUS

\begin{tabular}{cc}
\hline Pertanyaan & Skor \\
\hline Q1 & 4 \\
Q2 & 1 \\
Q3 & 3 \\
Q4 & 2 \\
Q5 & 3 \\
Q6 & 4 \\
Q7 & 3 \\
Q8 & 4 \\
Q9 & 4 \\
Q10 & 1 \\
Jumlah & 29 \\
Jumlah x 2,5 & 73 \\
\hline
\end{tabular}

Hasil dari nilai rata-rata yang telah dilakukan 30 responden yang Ketika selesai melakukan Langkahlangkah dalam perhitungan, sesuai dengan aturan daripada SUS. Maka selanjutnya, total skor yang diperoleh adalah 2350, kemudian dibagi dengan jumlah daripada responden dengan cara menggunakan rumus dalam menemukan hasil rata-rata skor SUS sebagai berikut: 


$$
\begin{gathered}
\tilde{x}=\frac{\sum \tilde{x}}{n}=\tilde{x}=\frac{2333}{30} \\
\tilde{x}=77,8
\end{gathered}
$$

Ket: rumus rata-rata

$\tilde{x}=$ Skor Rata - Rata

$\sum \tilde{x}=$ Jumlah Skor SUS

$n=$ Jumlah Responden

Maka rata-rata hasil SUS yang diperoleh berasal dari semua responden. Hasil tersebut maka masuk ke kelompok dimana hasil pengujian yang dilakukan dengan menggunakan skor rata-rata yang diperoleh. Penilaian kelompok skor SUS pada aplikasi Course Online bisa dilihat pada tabel 3.

Tabel 3 Penilaian Skor SUS

\begin{tabular}{ccc}
\hline SUS Score & Nilai & Penilaian \\
\hline$>80.3$ & A & Sangat Baik \\
$68-80.3$ & B & Baik \\
68 & C & Kurang Baik \\
$51-68$ & D & Sangat Baik \\
$<51$ & F & Buruk \\
\hline
\end{tabular}

\section{Pembahasan}

Berdasarkan tabel 3 didapatkan hasil perhitungan rata-rata skor SUS mendapatkan 78,3 dengan rentang kecukupan yang berada pada posisi hampir tidak tinggi, pada skala grade menempati grade $B$ dan tulang terakhir pada sisi adjektiva berdiri berada pada posisi OK. Maka dari hasil perhitungan terhadap aplikasi Course Online ini adalah:

1. Skor rata-rata SUS yaitu 78,3 .

2. Tingkat penerimaan untuk digunakan adalah Marginal Tinggi.

3. Tingkat grade skala bergabung ke dalam kategori B.

4. Adjektif rating bergabung ke dalam kategori Ok.

Pada hasil yang diperoleh dalam penelitian tersebut maka aplikasi Course Online sudah sesuai dengan kebutuhan pengguna dan dikatakan sudah terpenuhi, kemudian aplikasi atau sistem ini akan dipublikasikan kepada publik.

\section{Simpulan}

Dengan metode System Usability Scale bisa digunakan sebagai sistem untuk menganalisa evaluasi akan aplikasi yang dinilai sudah terukur, terstruktur dan juga sudah akurat. Maka dari hasil analisis yang dilakukan terhadap aplikasi Course Online ini sudah dikatakan berhasil dengan skor SUS 78,3. Sehingga user interface dan user experience sudah memenuhi kriteria pengguna yang baik dan menarik.

\section{Referensi}

Aji, H. P., \& DPA, N. R. (2020). Analisis Perbandingan Website Digilib dengan Metode Penghitungan Usability Menggunakan Kuesioner SUS. Jurnal Buana Informatika, 11(1), 63. https://doi.org/10.24002/jbi.v11i 1.2502

Damayanti, C., Triayudi, A., \& Sholihati, I. D. (2022). Analisis UI / UX Untuk Perancangan Website Apotek dengan Metode Human Centered Design dan System Usability Scale. 6, 551-559. https://doi.org/10.30865/mib.v6i 1.3526

Ependi, U., Panjaitan, F., \& Hutrianto, H. (2017). System Usability Scale Antarmuka Palembang Guide Sebagai Media Pendukung Asian Games XVIII. Journal of Information Systems Engineering and Business Intelligence, 3(2), 80. https://doi.org/10.20473/jisebi.3. 2.80-86

Fitriansyah, A., \& Harris, I. (2018). Pengukuran Kepuasan Pengguna Situs Web Dengan Metode End User Computing Satisfaction (EUCS). Query: Jurnal Sistem Informasi, 2(1), 1-8. http://jurnal.uinsu.ac.id/index.ph p/query/article/view/1552

Geasela, Y. M., Ranting, P.-, \& Andry, J. F. (2018). Analisis User Interface terhadap Website Berbasis ELearning dengan Metode Heuristic 
Evaluation. Jurnal Informatika, 5(2), 270-277. https://doi.org/10.31311/ji.v5i2.3 741

Hartawan, M. S. (2019). Analisa user interface untuk meningkatkan user experience menggunakan usability testing pada aplikasi android pemesanan test drive mobil. Jurnal Teknologi Informasi ESIT, Universitas Krisnadwipayana, 14(2), 46-52.

Maryati, I., Nugroho, E. I., \& Indrasanti, Z. O. (2022). Analisis Usability pada Situs Perpustakaan UC dengan Menggunakan System Usability Scale. 6, 362-369. https://doi.org/10.30865/mib.v6i 1.3472

Muqoddas, A., Yogananti, A. F., \& Bastian, H. (2020). Usability user interface desain pada aplikasi ecommerce. Jurnal Desain Komunikasi Visual \& Multimedia, 06(December 2019), 73-82.

Nugraheny, D. (2016). Analisis dan pada Sekolah Tinggi Teknologi Adisutjipto Yogyakarta. Seminar Nasional Teknologi Informasi Dan Kedirgantaraan (SENATIK), II, 2528-1666.

Pratama, A., Faroqi, A., \& Mandyartha, E. P. (2021). Analisis Tingkat Usability Pada Aplikasi Frostid Menggunakan System Usability Scale (SUS). Jurnal Ilmiah Edutic: Pendidikan Dan Informatika, 8(1), 31-38.

https://doi.org/10.21107/edutic.v 8il.12195

Rasmila, R. (2018). Evaluasi Website Dengan Menggunakan System Usability Scale (SUS) Pada Perguruan Tinggi Swasta di Palembang. JUSIFO (Jurnal Sistem
Informasi), 4(1), 89-98. https://doi.org/10.19109/JUSIFO. V4I1.2445

Santoso, J. (2018). Usability User Interface dan User Experience Media Pembelajaran Kamus Kolok Bengkala Berbasis Android. Jurnal Sistem Dan Informatika, 12(2), 174-181.

Sidik, A. (2018). Penggunaan System Usability Scale (SUS) Sebagai Evaluasi Website Berita Mobile. Technologia: Jurnal Ilmiah, 9(2), 83.

https://doi.org/10.31602/tji.v9i2. 1371

Utami, N. W., Arthana, I. K. R., \& Darmawiguna, I. G. M. (2020). Evaluasi Usability Pada E-Learning Universitas Pendidikan Ganesha Dengan Metode Usability Testing. Jurnal Nasional Pendidikan Teknik Informatika (JANAPATI), 9(1), 107. https://doi.org/10.23887/janapati .v9i1.23663

Veitch, E. A., Kaland, T., \& Alsos, O. A. (2021). Design for resilient human-system interaction in autonomy: The case of a shore control centre for unmanned ships. Proceedings of the Design Society, 1(August), 1023-1032. https://doi.org/10.1017/pds.2021 .102

Yonata, Y., Sipayung, E. M., \& Theresa, N. (2020). Analisis User Interface Sistem Informasi Akademik Berbasis Mobile pada Aspek Usability (Studi Kasus: Aplikasi XYZ). Jurnal Telematika, 15(1), 55-62.

https://journal.ithb.ac.id/telemati $\mathrm{ka} /$ article/view/355 